\title{
Dream Weaving as Praxis: Turning Culturally Inclusive Education and Anti- Racist Education Into a Decolonial Pedagogy
}

\author{
Danielle Lorenz
}

University of Alberta

\begin{abstract}
Utilizing the parameters of the dreaming phase in the decolonizing framework developed by Poka Laeuni (2009), this paper investigates how culturally inclusive education and anti-racist education philosophies have been posited as potential approaches to decolonizing Canadian K-12 schools. To examine how culturally inclusive education manifests in Ontario's K-12 system as a result of the Ontario First Nation, Métis, and Inuit Educational Policy Framework, this paper explores three topic areas. First, I provide a literature review of culturally inclusive education; second, I offer a literature review of anti-racist education; and third, having assessed the shortcomings of the two pedagogies previously, I conclude that neither culturally inclusive education nor antiracist education is sufficient alone as decolonizing strategies. From this analysis, I hypothesize that by weaving components of the two pedagogies together, a possible decolonizing framework may be created.
\end{abstract}

Keywords: education; culturally inclusive education; anti-racist education; Indigenous education; decolonization 


\section{Dream Weaving as Praxis: Turning Culturally Inclusive Education and Anti-Racist Education Into a Decolonial Pedagogy}

As a result of the "civilizing" teachings in the Indian Residential School system (Battiste, 2011; Miller, 2001, 2009), education was not considered to be "benign or beneficial for Aboriginal peoples" and resulted in their exposure "to a combination of unquestionably powerful but profoundly deliberating forces of assimilation and colonization" (Battiste, 1998, p. 19). With the closure of residential schools formally beginning in the late 1960s (Miller, 2001), one of the primary matters of concern for First Nations, Métis, and Inuit (FNMI) continued to be education. The interest in education has not waivered, though the specific goals have changed, to some extent. Where initially the establishment of onreserve schools and the integration of urban First Nation populations as well as Inuit and Métis students into provincial schools were met with trepidation by Indigenous peoples, the focus has shifted to decolonizing education. By decolonization, I mean the removal of colonial structures in provincial classrooms through the development of education policies and curricula that suit the needs of Indigenous communities and students. ${ }^{1}$ In this essay, I investigate two educational frameworks that have been suggested as possible techniques to decolonize the Canadian education system in a way that is favourable to Indigenous children. ${ }^{2}$ I provide an overview of both culturally inclusive and anti-racist education techniques, examining how they are defined, what their purposes are, how they are envisioned, and what criticisms there are of each. It should also be noted that it is not my intent to set these two frameworks against each other in a binary even though I am comparing aspects of both; rather, I am discussing attributes of both in order for the reader to understand the similarities and differences between the two. Following my analysis of culturally inclusive education and anti-racist education, I illustrate why neither approach is suitable alone for a decolonizing educational framework. In so doing, I explain why an alternative solution is to weave the two approaches together and propose a new model reflective of the positive attributes of culturally inclusive and anti-racist education.

I consider this approach as a means for Indigenous peoples to relocate from Laeuni's (2009) third to fourth step in the decolonization process. ${ }^{3}$ Describing the third step as the dreaming phase, Laeuni (2009) states that this phase is the most important because it allows colonized peoples to "explore their own cultures, experience their own aspirations for the future, and consider their own structures of government and social order" (p. 155). This phase focuses on revaluation and creation, allowing current political, economic, social and judicial systems to be assessed to better-determine what will be to the greatest strength of the people (Laeuni, 2009, p. 155). Following the dreaming phase is the fourth, or commitment stage, whereas what was discussed in the community will be formulated into a single direction to "release themselves from the shackles of colonial patriotism" (Laeuni, 2009, p. 157). I postulate that Indigenous educators can utilize Laeuni's dreaming phase and allegorically weave together elements of inclusive and antiracist pedagogies to develop a decolonized education framework that will work in their communities as well as provincial schools. 


\section{Culturally Inclusive Education}

In the general sense, inclusive education uses a human rights approach wherein inclusive educators acknowledge the importance of diversity, openness to other voices and opinions, empowerment, and "celebrating 'difference' in dignified ways" (Barton, 1997, pp. 233-234) so all children regardless of their dis/abilities will receive an education. In other words, the goal of inclusive education is to embrace the needs and opinions of those who are traditionally marginalized in education systems to benefit all students. Based on its name, it is assumed that culturally inclusive education is an educational approach that embraces a culture or many cultures. Using the same thought process, Indigenous culturally inclusive education is comprised, therefore, of particular aspects of Indigenous cultures. However, the etymology of culture/culturally and inclusive makes the meaning of culturally inclusive education more nuanced than it initially appears. Thus, to comprehend the implications of teachers employing culturally inclusive education, I offer a discussion of its definition, the reasons why teachers should utilize culturally inclusive education, what it looks like in practice, and four critiques of the philosophy. I show that culturally inclusive education alone is not the most suitable approach because it may further marginalize Indigenous peoples (Anuik, 2010; Doige, 2003; Leavitt, 1995; Neegan, 2005; Restoule, 2011), it utilizes an "add and stir" mentality (Battiste, 1998; Bauer-Dantoin \& Ritch, 2005; Cummins, 1989), it may cause teachers to be apprehensive about including Indigenous content based on their own education (Battiste, 1998; Kanu, 2005; Restoule, 2011; Schissel \& Wotherspoon, 2003; Taylor, 1995). and finally it follows the goals of official multiculturalism too closely (Bannerji, 2000; Cherubini, 2011; Egan, 2011; Galabuzi, 2011; Mackey 2002, 2012; Orlowski, 2008; Razack, 2007; Simpson, James, \& Mack, 2011; St. Denis, 2011; Thobani, 2007).

\section{Defining Culturally Inclusive Education}

Despite what may seem to be synonymous terms, inclusive education and culturally inclusive education are not the same thing. Interestingly, the scholarly literature does not provide an explanation of culturally inclusive education, assuming the reader is already familiar with the concept. Curriculum documents on the other hand do provide clarification that the literature does not. The Ontario Ministry of Education (2009) for example defines culturally inclusive education as "Education that is based on the principles of acceptance and inclusion of all students. Students see themselves reflected in their curriculum, their physical surroundings, and their broader environment, in which diversity is honoured and all individuals are respected" (p. 4). Likewise, the scholarly literature does not elucidate of what Indigenous culturally inclusive education consists. As a result, for the purpose of this paper, I define Indigenous culturally inclusive education as education that includes Indigenous epistemologies, ontologies, and axiologies as part of the curriculum.

\section{Culturally Inclusive Education: Cultural Difference Equated With Deficiency}

Indigenous culturally inclusive education is situated around the idea of cultural difference: Western ways of knowing are seen as being fundamentally dissimilar to Indigenous epistemologies, thereby making it challenging for Indigenous children to understand the material being presented to them (Anuik, 2010; Archibald, 1995; Kanu, 
2002). An after-effect of race-based policies from the $19^{\text {th }}$ century, was that students who were labelled culturally different-Indigenous peoples and other minorities ${ }^{4}$ - were considered culturally deprived and were placed in remedial classes since cultural difference was seen as an obstruction to learning and success (Anuik, 2010; Archibald, 1995; Kanu, 2002, p. 99). Otherwise known as cultural discontinuity, this mindset refers to the belief that the failures of Indigenous children were a result of them being unable to adjust to settler culture (Ledlow, 1992 as cited in St. Denis, 2009, p. 170). Even though culturally different is no longer (supposed to be) equated with cultural deficiencies (Anuik, 2010, p. 90), the variances between Western and Indigenous cultures are assumed to make Indigenous students less capable to learn based on their home environments. As Battiste (2009) explains, some teachers believe that the enculturation of Indigenous children in their families and homes is so markedly distinct from their settler peers that when they enter mainstream classrooms, learning problems result. Even though the idea of difference is not supposed to be equated with deficiency in classroom settings, Indigenous students are often infantilized and denigrated (Schmitt, 1996, p. 36), their educational needs not considered legitimate due to their construction as the Other. As St. Denis (2009) clarifies, "cultural Others" (p. 176) are thought to not have the same capacity for success as their dominant society peers; their vulnerability and compliance are seen as permitting the evasion of racism and classism in education. Consequently, FNMI cultural differences are naturalized, preserving Indigeneity as racially inferior (Hall, 1997, p. 245) even though race is a social construct.

\section{Culturally Inclusive Education: Including Indigenous Cultures}

A way to increase Indigenous students' academic success according to ideas of cultural difference is to focus on the inclusion of their cultures in the curriculum. Based on this argument, examples from the students' cultures are thought to be "the entry point of the teaching-learning process" (Kanu, 2005, p. 51) since Indigenous students have a unique understanding of the world compared to settler students (Doige, 2003, p. 143). This would motivate Indigenous students to engage in their course materials giving them a better chance of success in their studies (Goulet, 2001, 2005; Leavitt, 1995; Melnechenko \& Horsman, 1998; Redwing Saunders \& Hill, 2007; Silver, Mallett, Greene, \& Simard, 2002; Starnes, 2006 quoted in MacIver 2012, p. 159; Rolheiser, Evans, \& Gambhir, 2011). Looking at Saskatchewan in the early 1970s, Anuik (2010) states that school administrators and educators believed that curriculum with Métis content would facilitate student engagement and learning, thereby, "keep[ing] Métis students in school and rescu[ing] them from the margins of Prairie society" (p. 93). In turn, this would facilitate students' abilities to graduate "proficient in English and ready to attend postsecondary institutions or join the workforce" (Anuik, 2010, p. 93). Culturally relevant materials used in present-day classrooms are used to motivate Indigenous students to learn the skills deemed necessary for success by the provincial/territorial government, which are "English literacy, numeracy, and citizenship" (Anuik, 2010, p. 89), allowing them to advance to post-secondary education or the workforce after graduation, and thereby facilitating their integration into Canadian society.

Culturally inclusive education is viewed as a way for students to bridge their own cultures with Canadian culture within the classroom, which will encourage their 
engagement and participation rather than contribute to further marginalization (Restoule, 2011). In 1970s Saskatchewan, a small switch - for example teachers singing "Trapper in the Bush" instead of "Farmer in the Dell" - was believed to be one example of how students could be helped "to adjust to Eurocentric schools in their communities" (Anuik, 2010 , p. 89). Because many families still trapped at that time, it was thought that children would connect better to their course material if their teachers offered them related elements. In the present, as Neegan (2005) elucidates, it is important for the well-being of FNMI children to see the positive historical and contemporary contributions of Indigenous peoples, which may include topics such as languages, foods, and medicines (p. 11). These additions are considered ostensibly attainable, causing some ministries of education to advocate for culturally inclusive education models.

The Ontario Ministry of Education (2007b) for instance has developed a "curriculum that facilitates learning about contemporary and traditional First Nation, Métis, and Inuit cultures, histories, and perspectives" (p. 7). Some examples from the Ontario curricula include taking a high school course in Native Studies or a First Nations language (Ontario Ministry of Education, 2007a), or being guided through a series of activities on residential schools (Ontario Ministry of Education, n.d). However, there are certain issues with this kind of cultural inclusion. First, for the Native Studies and languages courses, there must not only be enough interest for the courses to be offered but, especially in regards to the language classes, the teacher must be qualified to lecture on the course content. Second, in other subject areas, the teacher's comfort level and education, and the school's resources impact whether or not Indigenous content is brought into the classroom.

\section{Reasons Why Teachers Do Not Include Indigenous Knowledges}

The lack of specificity in how teachers are supposed to accomplish culturally inclusive education has some worrying implications. As Henderson (2009) explains, Indigenous cultures are

displayed through the identification and elaboration of matters such as language, child-rearing practices, totems, taboos, signifying codes, work and leisure interests, standards of behaviour and deviance, systems of social classification, and jural procedures shared by members of the studied people. (p. 254)

Many of these aspects of a particular culture require substantial knowledge and understanding to be able to articulate in a way that does not marginalize or offend the peoples being discussed. Since the majority of settlers - teachers included of course-do not have significant background knowledge of these matters (Alfred, 2010; Howard \& Proulx, 2011), it is easier to avoid addressing these topics altogether than it is to take the initiative to learn more. Leavitt (1995) indicates that the majority of Indigenous content that is easy to include in lesson plans consists of material culture, or "the objects and skills pertinent to a people's ecology and economy" (p. 126). Additionally, spiritual beliefs and legends "are treated as artifacts, and these, together with descriptions of kinship patterns, transportation and hunting techniques, and the names of languages, tools and food plants" (Leavitt, 1995, p. 127) construct Indigenous peoples as static and caught 
in the past. Likewise, Doige (2003) states that culturally inclusive activities in schools may include "speakers in traditional dress, traditional foods, and displays of Aboriginal artifacts" (p. 150), which do not help eliminate stereotypes or facilitate understanding between settlers and Indigenous peoples. Instead, these activities "emphasize differences to such an extent and in such a way that the gap between people of Aboriginal and nonAboriginal cultures is widened, not bridged" (Doige, 2003, p. 150). Battiste (1998) finds cultural inclusion demonstrated by teachers in this way reductionist, assigning a panIndigenous identity to FNMI individuals through material objects such as tepees, totem poles, tomahawks, "beads, buffalo and bannock" (p. 22). This type of culturally inclusive framework is a gross generalization of Indigenous cultures.

Although Battiste (1998) acknowledges there has been a movement toward inclusive education, "mainstream knowledge has not been questioned or reconsidered; rather, the Other is acknowledged as a knowledge, not the knowledge" (p. 21). Culturally inclusive education framed in this way is only incorporating Indigenous peoples symbolically rather than treating them as true equals in mainstream education. Citing Cummins (1989), this add-and-stir educational model does not allow students to "reconcile their position in society or find the awareness or means to overcome the root problems of their oppression" (Battiste, 1998, p. 21). Reflecting on their experiences of school boards' requests for them to help teachers to include Aboriginal content in the classroom, Stan and Peggy Wilson (2002) state:

This request is made with good intentions, but with little thought about how the context affects either the process or the product. But it is like someone claiming that she or he is going to make buffalo and rabbit stew with one buffalo and one rabbit: it would be difficult to find the rabbit in that pot of stew. (p. 67)

After adding one buffalo and one rabbit to the pot, stirring the stew from time to time, and letting it simmer, it would be somewhat hare-brained to wonder why it tastes like buffalo rather than rabbit. Unfortunately, this rather unpalatable recipe for cultural inclusion in the classroom may be the only one available: It is up to the teacher to decide whether or not $\mathrm{s}$ /he wants to put the effort into creating a classroom environment that is mindful of Indigenous cultures.

Based on results of a study on Manitoba high school social studies teachers, Kanu (2005) reports "On average, each teacher had integrated Aboriginal perspectives into the social studies curriculum only six times over the entire academic year" (p. 56). Kanu's (2005) study is indicative of other teacher perceptions of Indigenous and culturally inclusive curricula; teachers mostly ignore Indigenous content. A significant concern with implementing an Indigenous culturally inclusive framework is having teachers and educators introduce the framework in a way that does not marginalize or tokenize Indigenous peoples vis-á-vis an add and stir approach. Some teachers are hesitant to include culturally inclusive material in their lesson plans because they do not have prior knowledge or understanding of Indigenous cultures, histories, and knowledges (Kanu, 2005; Restoule, 2011; Schissel \& Wotherspoon, 2003; Taylor, 1995). Kanu (2005) calls this apprehension "professional vulnerability" (p. 57), suggesting that teachers do not want to appear unknowledgeable to their students and perhaps more importantly in their 
eyes, to their principals. This lack of knowledge, I believe, is a direct result of what teachers learned while they were students. Battiste (1998) explains that because Indigenous content is not part of most academic disciplines, except those explicitly labeled Indigenous Studies at the university level, and because not much FNMI course content has been included in secondary and elementary curricula in the past, teachers are unlikely to have Indigenous material in their own classrooms. Ultimately, this speaks to the absence of Indigenous education in Canada, not only at the post-secondary level but also in several provincial and territorial K-12 curricula. Furthermore, this suggests that having a mandatory Indigenous education class in Bachelor of Education degree programs would be beneficial since it would expose preservice teacher candidates to Indigenous histories and cultures that they may not otherwise encounter during their undergraduate education.

Although a lack of knowledge about Indigenous cultures and histories is the mostcited reason why teachers do not include Indigenous knowledges in their classrooms (Battiste, 1998; Kanu, 2005; Restoule, 2011; Schissel \& Wotherspoon, 2003; Taylor, 1995), there are several other possibilities. These include "the lack of Aboriginal classroom resources; the racist attitudes of non-Aboriginal staff and students; school administrators' lukewarm support for integration; and incompatibility between school structures and some Aboriginal cultural values" (Kanu, 2005, p. 57).

\section{Solutions Offered}

Offering solutions to these issues, Restoule (2011) suggests through "seeking and maintaining relationships with [I]ndigenous people and organizations, non-Aboriginal teachers can gain knowledge that will help them generate meaningful classroom activities and deepen friendships" (p. 18). Here, although the onus is placed on teachers, pursuing assistance from outside of their school may help teachers develop the connections needed to have, for example, Elders come into the class to tell their creation story, or to develop a relationship with an on-reserve class of the same grade level. Kanu (2005) recommends "professional development opportunities for teachers unfamiliar with Aboriginal cultures and histories, so that appropriate materials and the contexts in which to use them can be identified" (p. 64). Kanu (2005) identifies not only the importance of having teachers be better educated, but also the desire of teachers to have training and leadership opportunities available to them. In essence, as Schissel and Wotherspoon (2003) explain, even if teachers support new initiatives such as Indigenous and culturally inclusive education they "require sufficient input, commitment from administrators and peers, background preparation, resource support, and confidence in the efforts of other teachers" (pp. 118-119) before they are able to engage in the initiative. Perhaps the irony here is that the issues surrounding teacher adoption of culturally inclusive education revolve around a general lack of education and learning on Indigenous histories and cultures in the first place.

\section{Culturally Inclusive Education and Multiculturalism}

At first glance, it seems that culturally inclusive education is part of Canada's image of a multicultural nation. As the Canadian Multiculturalism Act (1988) outlines: 
The Constitution of Canada provides that every individual is equal before and under the law and has the right to the equal protection and benefit of the law without discrimination and that everyone has the freedom of conscience, religion, thought, belief, opinion, expression, peaceful assembly and association and guarantees those rights and freedoms equally to male and female persons. (p. 2)

However, many scholars argue that multiculturalism is a myth since it reinforces White and settler norms and values rather than promoting equality between different groups (Bannerji, 2000; Egan, 2011; Galabuzi, 2011; Mackey 2002, 2012; Razack, 2007; Simpson, James, \& Mack, 2011; St. Denis, 2011; Thobani, 2007). Furthermore, multicultural policies do not recognize Indigenous rights to land and sovereignty (Cherubini, 2011) and the centuries of struggle between Indigenous peoples and settlers (Orlowski, 2008). Thus, official multiculturalism reinforces settler values and rights to land rather than treating Indigenous peoples as equals and rightful inhabitants of the land. As a state policy, the Canadian Multiculturalism Act (1988) is reinforced through the provincial and territorial curricula of K-12 schools since educational norms and values are written into curricula by government. Including culturally inclusive education as part of the multicultural education agenda implies that Indigenous "content and perspectives are to be regarded as merely one perspective among many" (St. Denis, 2011, p. 313), while a predominantly Anglophone Eurocentric point of view is emphasized. Furthermore, it promotes the add and stir method of teacher instruction, since Indigenous peoples, cultures, and histories are used as sources of enrichment rather than as principal parts of the curriculum (Mackey, 2002 as cited in St. Denis, 2011, p. 314). Thus, multicultural education policies - of which culturally inclusive education is one"effectively limit meaningful incorporation of Aboriginal content and perspectives into public schools," while simultaneously functioning as an aspect of colonialism that "works to distract from the recognition and redress of Indigenous rights" (St. Denis, 2011, pp. 307-308). Strictly speaking, culturally inclusive education is a limiting educational framework that does not facilitate decolonizing education.

\section{Culturally Inclusive Education: Insufficient}

In sum, culturally inclusive education is conceived to be a way to include aspects of Indigenous cultures in education, which is believed to facilitate FNMI children's interests in learning, thereby, enticing them to succeed. Substitutions such as singing "Trapper in the Bush" instead of "Farmer in the Dell" are an example of current reform; however, this add and stir mentality of updating curriculum may reinforce stereotypes of Indigenous peoples. Some teachers, knowing that they do not have adequate knowledge of Indigenous histories and cultures, are apprehensive of teaching Indigenous content: first, because they are aware that their ignorance may be defamatory to Indigenous peoples, and second, because it may make them look poorly in their administration's eyes. Culturally inclusive education, therefore, operates as part of Canada's official multiculturalism policy, negating Canada's ongoing colonial framework and continues to affect the lives of Indigenous peoples. 


\section{Anti-Racist Education}

Much of the rationale for settling what would become Canada was justified by racializing non-European peoples. This justification gave settlers permission to settle Canada because (a) humans could be divided into groups called races, (b) race determined the physical features and intelligence of humans, and (c) Whites were superior to all other races, and therefore, had the right to control all other humans (Vickers \& Issac, 2012). Although late $20^{\text {th }}$ century researchers have suggested that the genetic basis for race has been disproven (Lewontin, 1972), race still exists as a social construct (Dei, 1996; O’Brien \& Szeman, 2004; Smith, 2012; Vickers \& Issac, 2012; Walcott, 2011). However, even as a social construct, race continues to influence Canadian society (Simpson, James, $\&$ Mack, 2011). Since racial relations are an ongoing issue, several scholars believe that this dilemma may be improved, or possibly fixed through an anti-racist education framework. Dei (1996) defines anti-racist education "as an action-oriented strategy for institutional, systematic change to address racism and the interlocking systems of social oppression" (p. 25). Elaborating further, Dei (1996) states that anti-racist education is "a critical discourse of race and racism in society and of the continuing racializing of social groups for different and unequal treatment," and also a framework that "names the issues of race and social difference as issues of power and equity rather than matters of cultural and ethnic variety" (p. 25). Recognizing that anti-racist education is a second possible means of decolonizing the Canadian education system, I provide additional information about its definition, an explanation as to why scholars wish to implement it, an outline of how it functions in practice, and three critiques of this model. I show that it is perhaps not an ideal approach because teachers and students often resist it (Dei, 2007; St. Denis \& Schick, 2003; Sterzuk, 2010); it has a history of ignoring Indigenous peoples (Lawrence $\&$ Dua, 2011); and it has been criticized as not offering demonstrable solutions (Donald, 2009; Ellsworth, 1989; Thompson, 2003).

\section{Race as Social and Ideological Construct}

Acknowledging that race is a social and ideological concept is important: "Everyone is differently burdened by the history of racism and all other discriminations in society" (Dei, 1999, p. 13). Even though not all people may have experienced racial discrimination, racism still exists and informs societal relationships. Discrimination based on racial identities is problematic because, as Calliou (1995) states, "Racism hurts; antiracism is not just about changing disliking into liking through cultural exposure. Antiracism involves the application of compassionate insights to begin healing amongst ourselves" (p. 63). Consideration of others is a fundamental component of anti-racist education, requiring an effective teacher to communicate how race functions in society to his/her students (Calliou, 1995). Borg and Mayo (2007) conceptualize anti-racist education through the acknowledgement of racism as a reversible social category. Similarly, Dei (2007) recognizes that teachers utilizing anti-racist education in their classrooms aspire to social change in such a way that race is recognized as a pre-eminent power structure that leads to inequalities among different groups of people regardless of what other forms of oppression may exist. Additionally Dei (1996) acknowledges that anti-racist education requires integration "with family life, homecare, daycare, schools and the various communities in which we live and work" (pp. 11-12) before true societal change can occur. In other words, anti-racist education relies on understanding race as a 
social and ideological construct that informs privileges in some individuals and disadvantage in others.

\section{Difference as it Relates to Power}

St. Denis (2009) states:

Rather than acknowledging the need for critical examination of how and why race matters in our society, it is often suggested that it is Aboriginal people[s] and their culture[s] that must be explained to and understood by those in position of racial dominance. (p. 163)

St Denis's (2009) point touches on the problem with an emphasis on difference: that Indigenous peoples are inherently different from the settler population, and that it is these dissimilarities that require explanation, rather than the existing racial hierarchies and social stratification. Because ideas of differentiation are connected with deficiencies (Anuik, 2010; Archibald, 1995; Battiste, 2009; Hall, 1997; Kanu, 2002; Schmidt, 1996; St. Denis, 2009), this model causes Indigenous peoples to be accepted as subservient. As Dei (2007) notes, “'Difference' is a site of power and oppression. Difference is also a site of possibility enabling human subjects to work with experience and critical self-reflection for collective political action" (p. 189). Because differences need to be acknowledged as social realities when working toward a more equitable society, teachers "must understand and teach about differences and how they are related to power. How Canadians respond to such themes in educational contexts is used to illustrate the value of an integrative, anti-racism discourse" (Dei \& James, 2002, pp. 65-66). To remedy this, "Difference should be taught in a manner that recognizes our individual and collective strengths. Differences should not be taught in a manner that renders exotic and romanticizes the 'other" (Dei, 1996, p. 37). Anti-racism education as a framework stems from the acknowledgement of how racialized differences lead to inequality and "working towards understandings and practices that transcend race-based power relations and other forms of equality" (Wotherspoon, 2009, p. 241). Clearly, "race hierarchies shape and/or demarcate our schools, communities, workplaces social practices and lived experiences" (Dei, 2007, p. 188).

It is important to note that racial hierarchies have existed in some form for close to 400 years and that much of how racialized strata function today is a direct result of what has come before. As Gillborn (2005) states, curricula are designed with the aim of benefitting the mainstream society, and in the case of Canada, this society is predominantly White and Anglophone. Canadian curricula and teachers have historically misrepresented Indigenous peoples as inferior, child-like, or a "dying race" (Francis, 2000), continually reaffirming settler dominance. In response to this mentality, an antiracism framework critiques White privilege and power as developed through slavery, colonization, and misrepresentation of Indigenous and non-White peoples globally (Dei, 1996, p. 29). Furthermore anti-racism education "interrogates White privilege and the ideology that maintains and supports both Whiteness as a social identity and the dominant institutions of society" (Dei, 1996, p. 28). Bringing anti-racism education into the classroom and into teacher practice, therefore, may help to dismantle some of the power dynamics that exist. 


\section{Implementing Anti-Racist Education}

Because children spend a significant amount of their waking hours at school, the role that teachers play in developing an anti-racist framework is important. Dei (1996) believes that "schools are not only agencies for cultural, political, and economic reproduction; they are also sites of contestation between groups differently situated in terms of power relations" (p. 21). This is why he sees it as the teacher's role to inform students "of the racial, class, gender and sexual implications of whatever is taught in the classroom" (Dei, 1996, p. 17). Likewise, Buttaro (2010) thinks that teachers should be "deliberately bringing issues of race, difference and power into central focus," as a way to move away from a "color-blind curriculum and a neutral assimilation process" (p. 9). Thus, the onus of enacting anti-racist education is primarily on the teacher. It can be part of the curriculum also; however, in order for this to occur there must be a discussion of how the concepts of race and social location impacts peoples positions in society.

The application of anti-racism education in the classroom is dependent wholly on the school administration. As Dei (1996) notes, a goal of anti-racist educators is to teach students how people in mainstream culture manipulate the acknowledgement and awareness of marginalized people within educational institutions. An additional goal is to instruct that "blaming the victim" and "culture deficit" (Dei, 1996, p. 38) models of understanding social problems contribute to subordination. If a teacher is not considerate of how blaming occurs or believes that cultural deficiencies exist, it is more or less impossible for teachers to implement an anti-racist framework in the classroom. In creating an anti-racist education framework, Dei (1996) advocates for an education system that works for the common good of everyone, determined through the lived experiences of people of diverse backgrounds. The open-endedness of anti-racism education is a valuable asset because teachers are free to develop their lesson plans how they would like. For example, teachers could assign older students a project that involves comparing and contrasting the residential school experiences of Indigenous peoples from Canada, Australia, and the United States. Another possibility is to write a report on a specific Indigenous activist group, outlining their goals and achievements. The focus on collective action is important since anti-racism pedagogies focus on mobilization, action and advocacy as being equal to understanding the history behind racial constructions (Borg \& Mayo, 2007).

Dei (1996) outlines the following 10 principles for teachers to instigate an antiracist educational framework in class:

1. Anti-racism educators identify race as a social construction rather than a biological fact (p. 27).

2. Anti-racism education educators clarify that one is only able to understand the impact of race when considering how it intersects with other forms of social oppression (p. 28).

3. Anti-racism educators interrogate "White (male) power and privilege and the rationality for dominance in society" (Dei, 1996, p. 28). 
4. Anti-racist educators illustrate how the marginalization of certain peoples and groups delegitimized their knowledges and causes their subordination in the education system (pp. 29-30).

5. Anti-racist educators state that education must be holistic in nature so that it incorporates cultural, social, political, ecological and spiritual aspects (p. 30).

6 Anti-racism education ascertains that the concept of identity is important ( $\mathrm{p}$. $31)$.

7. Anti-racist educators ascertain "the pedagogic need to confront the challenge of diversity and difference in Canadian society” (Dei, 1996, p. 33).

8. Anti-racist education recognizes how mainstream education has traditionally produced and reproduced racial inequalities in society (p. 34).

9. Anti-racist educators emphasize the issues children may face at school due to their social location and how this may affect how they function in the school environment (p. 35).

10. Anti-racist education interrogates the idea that the family or home is the cause of the "problems" that children face with respect to their learning (p. 35).

When used in conjunction with each other, these principles make students more aware of how Canadian society works on an ideological level. However, there are no examples of how to implement this framework in curricula; anti-racist education exists on a theoretical and abstract level, which may make it challenging for teachers to utilize it in the classroom. Nevertheless, Dei and James (2002) believe that through "acknowledging and responding to difference, educators might not only challenge power and privilege, but they might also enable students to use their individual and collective agencies to work for change that furthers equality, thereby enriching and strengthening our social fabric" (p. 83). Although there is nothing wrong with Dei's (1996) principles - and in terms of my own pedagogical approach are principles I try to utilize where possible-it is one matter to outline them and it is a whole other matter to have a teacher use them.

\section{Receptivity and Resistance to Anti-Racist Education}

Before an anti-racist educational framework is implemented, the teacher must determine how receptive the students in the class may be. Perhaps even more important than that is whether teachers are amenable to using the framework in the first place. As St. Denis and Schick (2003) explained, if anti-racist education is made mandatory "students perceive the course as an infringement on their liberty even before they enter the class...A requirement to learn of the other challenges students' self-images as already knowledgeable and sympathetic to difference" (pp. 56-57). If a teacher pushes students too far, especially students at the intermediate and secondary levels, it is likely that they may become apathetic to anti-racist lesson plans. Colour-blind rationale, exhibited through phrases such as "I don't see race," or "we need to get along," illustrate how students "do not acknowledge that people are differently positioned in hierarchical structures that depend on social and political difference," allowing them to ignore and trivialize "the significance of unearned privileges conferred by their own dominant group 
identity" (St. Denis \& Schick, 2003, p. 66). In so doing, students resist learning because they are constantly blaming the victim for faults that they see as being separate from themselves. A different and subversive tactic that may not be identifiable to the teacher is for students to parrot the goals of the lesson and the teacher (Sterzuk, 2010, p. 111). In this instance, even though it appears that the students have absorbed the anti-racist framework; students are merely telling the teacher what s/he wants to hear rather than actually going through a personal process of change. Thus, although the child may be able to answer the questions and do the assignments according to an anti-racist framework, it does not mean they believe in anti-racism education.

Further, the teacher must also be willing to recognize differential levels of privilege and to understand how privilege functions in society. If they do not accept this message or are uncomfortable communicating it, students will not benefit from the instruction. Some of the rationale for not wishing to participate in anti-racist education revolves around the "fear of offending individuals and groups or in a concealed attempt to deny race privilege" (Dei, 2007, p. 188). The teachers who do not wish to acknowledge how their social location affects their lives, "are not necessarily interested in hearing the difficult things that need to be said or doing the difficult analysis of unpacking their assumptions about inequality" (St. Denis \& Schick, 2003, p. 55). It is possible that the teacher could pretend to believe in the anti-racist framework and teach it to his/her students, but in the end it is more likely that they would avoid it altogether. Effectively, teacher reluctance makes anti-racist education ineffective (Orlowski, 2008).

\section{Limitations of Anti-Racist Education}

Exclusion of Indigenous peoples in anti-racist education. Lawrence and Dua (2011) argue that anti-racism has a history of excluding Indigenous peoples even though Indigenous peoples deal with similar experiences as many people of colour. Indeed, although there was significant mention of race as a general concept in the literature surveyed, the relationship that Indigenous people have had and continue to have with racism is primarily absent. Canadian anti-racism is a part of an ongoing colonial framework, according to Lawrence and Dua (2011), because it neglects to recognize the ongoing colonization of Indigenous peoples in North America. In other words, people of colour, regardless of their origins - as descendants of slaves, migrant labourers, refugees or immigrants-live on land that was taken from Indigenous peoples and have certain privileges over Indigenous peoples due to the erasure of Indigenous rights to the land (Lawrence and Dua, 2011). Although anti-racism education deals primarily with race as a concept, understanding the historical context of the land in which people are being educated is also important. Thus, not only must teachers be aware of the history of colonization in Canada, they must also incorporate it as part of their anti-racism teaching philosophy. If anti-racist educational frameworks take a critical perspective of Canadian history in such a way that acknowledges how colonization negatively affected Indigenous peoples, it may go a long way in helping to diffuse some of the tension that exists between Indigenous peoples and settlers.

Lawrence and Dua (2011) make three recommendations for anti-racist educators to include Indigenous peoples in anti-racist pedagogies. First, anti-racist educators must acknowledge that anti-racist goals must be done through recognition of Indigenous 
sovereignty and restoration of land; second, they must acknowledge the ongoing colonialism and how it contributes to racialization of Indigenous peoples; and third, they must avoid a pluralist approach and structure their goals in a way that does not disenfranchise Indigenous peoples. However, although negotiating an anti-racism framework that considers Indigenous histories is contingent on whether the teacher approaches the topic to begin with, what Lawrence and Dua (2011) outline may be challenging for a teacher who does not have prior understanding of Indigenous cultures and histories.

No solution for racism. Perhaps one of the most limiting aspects of anti-racist education according to those who criticize it is that in some of the literature there is no solution provided for racism. Basing his opinions on personal observation as well as that of Ellsworth (1989) and Thompson (2003), Donald (2009) states that an issue with antiracist education is that although it identifies and interrogates racism within a society or group, it cannot be posited as a solution for eliminating racism once it has been identified. Consequently, it must be acknowledged that racism and racialization are systemic issues tied to colonialism (Alfred, 2011; Dei, 1996, 2009; Fanon, 1952; Hall, 1997; Lawrence, 2004; Lawrence \& Dua, 2011; Memmi. 2000; Said, 1978; Sensoy \& DiAngelo, 2012; Thobani, 2007; Vickers \& Issac, 2012) and that they require significant work and action before they can be eradicated from the hegemonic nation-state that is present day Canada. In other words, there is no solitary solution to end racism, but rather it is an effort manifesting in many different approaches by numerous people over generations. Another point coming from the literature is that anti-racist education does not suggest activities or methods for use in the classroom. Although the open-endedness can be beneficial for a teacher who is comfortable with an anti-racist approach to begin with, for a teacher who is not as relaxed or does not understand as well, there may be significant issues putting an anti-racist educational framework into classroom practice. Perhaps this pronounced lack of direction is a reason why students, but more especially why some teachers, may not want anti-racist curricula in the classroom. A lack of tangible results coming from a theoretical model may be dissuading teachers, administrators, parents, and students. However, this is not a reason for abandoning anti-racist pedagogies: giving up when times are difficult only yields power to racism and racists. ${ }^{5}$

In sum, anti-racist education is regarded as a way to discuss intersecting forms of oppression through race, ethnicity, class, gender, sexuality, language, culture, religion, and region in an effort to make the world more equitable for all. Anti-racism educators, in their efforts to eliminate subordination, focus on conversation rather than action. Some teachers reject teaching anti-racist education due to their own beliefs, due to their lack of understanding the idea of privilege, and possibly, due to a lack of tangible and real-world solutions. Students may rebuff anti-racist education for similar reasons.

\section{Dream Weaving as Praxis}

When comparing anti-racist education to culturally inclusive education, one can see that neither framework is a sufficient model on its own to facilitate the decolonization of education. I suggest weaving the two educational approaches together to develop what will ideally be a more effective framework. Building from dreaming phase explained by 
Laeuni (2009), I call the knitting together of culturally inclusive and anti-racism frameworks together dream weaving.

\section{Settler Canadians and Canada’s Colonial Past}

Some would argue that Canada is a postcolonial state, since the colonizing forces have left, making it a sovereign nation (Young, 2003, p. 3). Although the British and French have mostly cut their governing ties to Canada, the influence of the "founding nations" is still evident, and the colonizer-any settler person in the eyes of many Indigenous peoples - still remains. In other words, in the minds of many Indigenous individuals, Canada is a colonial state that needs to be decolonized (Alfred, 2005, 2010; Battiste, 1998; Corntassel, 2012; Iseke-Barnes, 2008; Lawrence \& Dua, 2011). As Smith (1999/2012) explains, "Decolonization, once viewed as the formal process of handing over the instruments of government, is now recognized as a long-term process involving the bureaucratic, cultural, linguistic and psychological divesting of colonial power" ( $\mathrm{p}$. 101). Decolonization is theorized as a way to improve relations between Indigenous and non-Indigenous peoples and remove systems of prejudice and oppression that affect Indigenous peoples. De Lissovoy (2010) acknowledges that to understand the importance of difference in society, a critical confrontation of "the histories of domination and violation within which they are constituted" (p. 282) needs to occur. Thus, settler Canadians must be aware of and acknowledge Canada's colonial past and current existence to move forward into a mutually beneficial place. There is not one solitary vision for what this may look like; however, the possibilities revolve around all peoples being treated equitably and being free from oppression. Although decolonization is meant to occur in all aspects of society, I am only discussing one small segment, that is, the decolonization of education. Accordingly, I briefly lay out a decolonization process and theorize how combining the culturally inclusive and anti-racist educational frameworks may work as a better and possible solution for decolonization than either of the two alone.

\section{Decolonizing Education: The Dreaming Stage}

It is important to note that there is no solitary and all-encompassing decolonizing educational framework, so what a decolonized education system looks like may vary between groups and individuals. Significant as well is how the colonial project affected traditional Indigenous educational systems and the steps taken to reclaim them to date. Laeuni (2009) suggests five stages to decolonization: (a) rediscovery and recovery, (b) mourning, (c) dreaming, (d) commitment, and (e) action (p. 152). Recall that I hypothesized that Indigenous peoples can be located in Laeuni's (2009) third stage - the dreaming stage — of decolonization. I propose that the Indian Residential School system greatly changed Indigenous cultures because children were forcibly separated from their families, prohibited from speaking their language and practicing their culture, and many received abusive and otherwise neglectful care from their caregivers and educators during their time there (Albanese, 2009; Fournier \& Crey, 2011; Lawrence, 2004; Miller, 2001, 2009; Regan, 2010; Schissel\& Wotherspoon; Wotherspoon, 2009; Wotherspoon \& Satzewich, 2000). Since the mass closure of residential schools starting in the 1960s, Indigenous peoples have begun their process of rediscovery and recovery. They have also mourned, not only for the family members who were required to attend residential 
schools, but also because of the colonial mindset that continues their marginalization. Now they are dreaming; they are discussing ways to decolonize themselves and their own communities. This is a process that has been occurring since the $19^{\text {th }}$ century, with Indigenous parents recognizing that only up to half of their children's education in residential schools would be considered academic ${ }^{6}$ and desiring more input into what their children were learning. ${ }^{7}$ Resistance to settler colonial management of Indigenous education is also evident in the Indian Control of Indian Education (National Indian Brotherhood/Assembly of First Nations, 1972) and First Nations Control of First Nations Education (Assembly of First Nations, 2010) among other policy documents. The federal government has been obstinate in relinquishing control-and funding - to Indigenous peoples, thereby slowing down and complicating the decolonial progression and causing a rift between the FNMI and settler populations. Alfred (2005) sees decolonization as a way to "remake the relationship between Onkwehonwe ${ }^{8}$ and Settler," inviting settlers "to share our vision of respect and peaceful coexistence" (pp. 34-35). Indeed, it is not until the non-Indigenous population agrees to be part of the decolonization process that change may be achieved and Indigenous people may move towards the commitment phase.

\section{Weaving Together Culturally Inclusive Education and Anti-Racist Education}

Despite anti-racist education being criticized as primarily ignoring Indigenous peoples and not offering practical solutions for change, it has demonstrated its importance in creating spaces that are more equitable for all peoples. The limitation of culturally inclusive education on the other hand, is that it tends only to infuse mainstream education with Indigenous elements, thereby creating a generalized explanation of Indigenous cultures. Both educational frameworks experience resistance within educational institutions from not only students but also teachers and administrators. The key is to weave both frameworks together, creating a decolonized educational framework. The strengths of a decolonized education system based on an anti-racist educational model are that (a) it draws on how different forms of oppression intersect, and thereby, affect individuals in their day-to-day lives; (b) it considers the history of colonization and ties it to the history of race as a social construct; and (c)it looks at how other kinds of oppression based on class, religion, gender, sexuality, and ethnicity may influence an individual's educational experiences. This ideally would be a reflexive process, facilitating the "unsettling of the settler within" (Regan, 2010) for non-Indigenous students and educators while simultaneously being a decolonizing movement for Indigenous students and teachers. In order to move decolonizing educational frameworks from theoretical orientations in anti-racist education and into something more practical, I believe that Indigenous knowledges should be an integral part of the curriculum, not an add-on in their present iteration through culturally inclusive education, but integrated in such a way that they are equal to Western knowledges. Many Indigenous academics (Cajete, 2008; Kincheloe \& Steinberg, 2008; Little Bear, 2000; Restoule, 2011; Simpson, 2008; Stewart-Harawira, 2005) advocate for the inclusion of Indigenous Knowledge (IK) as part of mainstream settler curricula, since IK is intrinsically inclusive in its design, approach and goals (Restoule, 2011; Cajete, 2008). As Henderson (2009) notes, "One task of decolonization is to replace the sameness of universality with the concepts of diversity, complementarity, flexibility, and equity or fundamental fairness" (p. 267). Thus, instead of there being only one universal (Western) idea of conceiving the world, 
Indigenous points of view are used as complementary systems that demonstrate the importance of diversity, equity, and flexibility. This idea connects to the idea of culturally inclusive education.

The strength of culturally inclusive education is its focus on how Indigenous perspectives, knowledges, and histories are implemented in curricula; however, part of the problem is that they are not being executed adequately, in my opinion. In order for the implementation to be successful, teacher education must be improved substantially. For preservice teachers, this would mean mandatory Indigenous Studies classes as part of their Bachelor of Education curricula and all classes within the B.Ed. program would integrate Indigenous content. Ideally, an Indigenous Studies course would also be made mandatory for all university students in order to facilitate a larger decolonizing process. Although, there are concerns with this implementation also being inadequate to the same level as secondary and elementary Indigenous course instruction, I speculate that it is more likely to have post-secondary instructors with proven knowledge in the Indigenous Studies subject area than it is to have primary and secondary teachers with this knowledge. Additionally, there should be more opportunities for professional development for in-service teachers so that they could increase their knowledge base and become more comfortable with Indigenous course material. Of all of the aspects of culturally inclusive education to be encouraged as part of the decolonizing educational framework, Indigenous knowledges are probably the most abstract because of how they differ from Western knowledges. Yet, in order for a decolonizing educational framework to transpire, non-Indigenous educators must embrace IK as part of their personal unsettling and decolonizing process.

Atleo and Fitznor (2010) believe that a decolonizing educational framework
should allow for the mutual understanding of "Aboriginal/First Nations/Métis/Inuit/Indigenous heritages and settler Euroheritage” (pp. 20-21). In this way, both the settler and Indigenous populations may be equally represented in the education system, which is reflective of Canada's early history as a nation. Kirkness (1998) calls for an education that is based in the community and its traditions and in so doing "disestablishing many of our existing practices based on theories of the society that has dominated us for so many years" (p. 11). This emphasis on the local is significant because the focus on local knowledge is recognized in IK practice and because it will better connect students to where they live regardless of their cultural background. Consequently, "the animation of Indigenous knowledge remains central to the formulation and implementation of balanced and transformative curricula in Canada" (Battiste, Bell, \& Findlay, 2003, pp. 85-86). The application of IK to educational institutions is important for both Indigenous and settler children because it allows both to decolonize. As Battiste and Henderson (2009) articulate, "We know that when IK is naturalized in educational programs, the learning spirit is nurtured and animated. Individually and collectively, Aboriginal people are able to decolonize themselves, their communities, and institutions, leading to transformation and change; and everyone benefits" (p. 13). Although Battiste and Henderson (2009) focus on Indigenous peoplesand justifiably so- what they outline is not egregious for settlers but rather can be seen as beneficial. In this manner, "The real justification for including Aboriginal knowledge in the modern curriculum is not so that Aboriginal students can compete with non- 
Aboriginal students in an imagined world. It is, rather, that immigrant society is sorely in need of what Aboriginal knowledge has to offer" (Battiste, 2009, p. 201). The goal here is not to develop parallel education systems but rather, a system that is beneficial for all children within Canada regardless of if they attend school on reserve or in a mainstream classroom. Even though many Indigenous parents want their children to be exposed to settler course content, "Aboriginal parents still wish for their children to...develop their personal and community potential through a fully actualized linguistic and cultural identity and from within their own Aboriginal context" (Battiste, 2009, p. 192). In other words, a decolonized educational framework would result from weaving together the historical and theoretical aspects of anti-racism education with the understanding of Indigenous cultures knowledges as part of the culturally inclusive education framework. If a decolonized educational framework of this kind is to be produced, it is not only the responsibility of Indigenous peoples but also the non-Indigenous population. A commitment to work together by the settler and Indigenous populations honours Laeuni's (2009) fourth stage of decolonization. Finally, once a decolonized educational framework is written and is being used in K-12 schools, Canadian education will be moving towards Laeuni's (2005) fifth and final phase: action.

\section{Conclusion}

This essay examined how culturally inclusive education is not an idyllic decolonizing framework on its own because it tends to further marginalize Indigenous peoples vis-ávis its add and stir mentality of cultural inclusion, which is indicative of Canada's problematic official multiculturalism policy. Similarly, anti-racist education is not a fitting decolonizing approach since it has been accused of ignoring Indigenous peoples and often does not offer applied solutions for classroom settings. Thus, I assert that a possible decolonizing framework comes from stitching together or dream weaving aspects of the two approaches. Although this framework has some considerable knots in its assembly, it is stronger than either culturally inclusive education or anti-racism education alone. However, the trick to executing a decolonizing approach in such a manner relies heavily on settler teachers willing to unsettle themselves for the mutual benefit of Indigenous and non-Indigenous children. As more settler teachers commit to decolonizing themselves, and more Indigenous teachers graduate from university, the more likely that a decolonizing approach can be put into action. 


\section{References}

Albanese, P. (2009). Children in Canada today. Don Mills, ON: Oxford University Press.

Alfred, T. (2005). Wasáse: Indigenous pathways of action and freedom. Peterborough, ON: Broadview Press.

Alfred, T. (2010). Foreword. In P. Regan (Author), Unsettling the settler within: Indian residential schools, truth telling and reconciliation in Canada (pp. ix-xi). Vancouver, BC: University of British Colombia Press.

Alfred, T. (2011). Colonial stains on our existence. In M. J. Cannon \& L. Sunseri (Eds.), Racism, colonialism and Indigeneity in Canada (pp. 3-10). Don Mills, ON: Oxford University Press.

Anuik, J. (2010). "In from the margins": Government of Saskatchewan policies to support Métis learning, 1969-1979. Canadian Journal of Native Education, 32, 83-99.

Archibald, J. (1995). Locally developed Native studies curriculum: An historical and philosophical rationale. In M. Battise \& J. Barman (Eds.), First Nations education in Canada: The circle unfolds (pp. 288-312). Vancouver, BC: University of British Colombia Press.

Assembly of First Nations (2010). First Nations control of First Nations education: It's our vision, it's our time. Retrieved from: http://www.afn.ca/uploads/files/education/3.2010 july_afn_first_nations_contr ol_of first_nations_education_final_eng.pdf

Atleo, M. R., \& Fitznor, L. (2010). Aboriginal educators discuss recognizing, reclaiming, and revitalizing their multi-competences in heritage/English-language use. Canadian Journal of Education, 32, 13-26.

Bannerji, H. (2000). The dark side of the nation: Essays on multiculturalism, nationalism and gender. Toronto, ON: Canadian Scholars Press.

Barton, L. (1997): Inclusive education: Romantic, subversive or realistic? International Journal of Inclusive Education, 1(3), 231-242.

Battiste, M. (1998). Enabling the autumn seed: Toward a decolonized approach to Aboriginal knowledge, language, and education. Canadian Journal of Native Education, 22(1), 16-27.

Battiste, M. (2009). Maintaining Aboriginal identity, language and culture in modern society. In M. Battiste (Ed.), Reclaiming Indigenous voice and vision (pp. 192208). Vancouver, BC: University of British Colombia Press.

Battiste, M. (2011). Micmac literacy and cognitive assimilation. In M. J. Cannon \& L. Sunseri (Eds.), Racism, colonialism and Indigeneity in Canada (pp. 165-172). Don Mills, ON: Oxford University Press. 
Battiste, M., Bell, L., \& Findlay, M. (2003). Decolonizing education in Canadian universities: An interdisciplinary, international Indigenous research project. Canadian Journal of Native Education, 26(2), 82-95.

Battiste, M., \& Henderson, J. Y. (2009). Naturalizing Indigenous knowledge in Eurocentric education. Canadian Journal of Native Education, 32(1), 5-18.

Bauer-Dantoin, A. C., \& Ritch, D. (2005). Moving beyond the "add and stir" approach to increasing diversity in the sciences: Design and implementation of an undergraduate course entitled ethnic minorities in science. Journal of Women and Minorities in Science and Engineering, 11(4), 329-343. doi:10.1615/JWomenMinorScienEng.v11.i4.20

Borg, C., \& Mayo, P. (2007). Toward an anti-racist agenda in education: The case of Malta. In T. Das Gupta, C. E. James, R. C. A. Maaka, G. Galabuzi \& C. Andersen (Eds.), Race and racialization: Essential readings (pp. 179-187). Toronto, ON: Canadian Scholars Press, Inc.

Buttaro, L. (2010). Decolonizing pedagogy in the American classroom. The Innovation Journal, 15(1), 1-31.

Cajete, G. (2008). Seven orientations for the development of Indigenous science education. In N. Denzin, Y. Lincoln, \& L. Tuhiwai Smith (Eds.), Handbook of critical and Indigenous methodologies (pp. 487-96). Thousand Oaks, CA: SAGE Publications.

Calliou, S. (1995). Peacekeeping actions at home: A medicine wheel model for a peacekeeping pedagogy. In M. Battise \& J. Barman (Eds.), First Nations education in Canada: The circle unfolds (pp. 47-72). Vancouver, BC: University of British Columbia Press.

The Canadian Multiculturalism Act (1988). R.S.C., 1985, c. 24 (4th Supp.). Retrieved from http://laws-lois.justice.gc.ca/eng/acts/C-18.7/

Cherubini, L. (2011). Using multiculturalism as a "new way of seeing the world": Ontario Aboriginal educational policy according to Foucault. International Journal of Multicultural Education, 13(2), 1-15.

Corntassel, J. (2012). Re-envisioning resurgence: Indigenous pathways to decolonization and sustainable self-determination. Decolonization, 1(1), 86-101.

Cummins, J. (1989). Empowering minority students. Sacramento, CA: California Association for Bilingual Education.

decolonization, (2013, March). In OED Online. Retrieved from http://www.oed.com.login.ezproxy.library.ualberta.ca/view/Entry/48333?redirec tedFrom $=$ decolonization .

Dei, G. J. S. (1996). Anti-racism education: Theory and practice. Halifax, NS: Fernwood Publishing. 
Dei, G. J. S. (2007). The denial of difference: Reframing anti-racist praxis. In T. Das Gupta, C. E. James, R. C. A. Maaka, G. Galabuzi \& C. Andersen (Eds.), Race and racialization: Essential readings (pp. 188-198). Toronto, ON: Canadian Scholars Press, Inc.

Dei, G. J. S. (2009). Theorizing anti-racism. In C. Levine-Rasky (Ed.), Canadian perspectives on the sociology of education (pp. 51-68). Toronto, ON: Oxford University Press.

Dei, G. J. S., \& James, I. M. (2002). Beyond the rhetoric: Moving from exclusion, reaching for inclusion in Canadian Schools. Alberta Journal of Educational Research, 48(1), 61-87.

De Lissovoy, N. (2010). Decolonial pedagogy and the ethics of the global. Discourse, 31(3), 279-293. doi:10.1080/01596301003786886

Dickason, O. P. (2006). A concise history of Canada's First Nations. Toronto, ON: Oxford University Press.

Dickason, O. P. (2009). Canada's First Nations: A history of founding peoples from earliest times $\left(4^{\text {th }}\right.$ ed.). Toronto, ON: Oxford University Press.

Doige, L. A. C. (2003). A missing link: Between traditional Aboriginal education and the Western system of education. Canadian Journal of Native Education, 27(2), 144-160.

Donald, D. T. (2009). The pedagogy of the fort: Curriculum, Aboriginal-Canadian relations, and Indigenous Metissage (Doctoral dissertation). Edmonton, Alberta: University of Alberta.

Egan, B. (2011). Recognition politics and reconciliation fantasies: Liberal multiculturalism and the "Indian land question." In M. Chazan, L. Helps, A. Stanley, \& S. Thakkar (Eds.), Home and Native land: Unsettling multiculturalism in Canada (pp. 123-141). Toronto, ON: Between the Lines.

Ellsworth, E. (1989). Why doesn't this feel empowering? Working through the repressive myths of critical pedagogy. Harvard Educational Review, 59(3), 297-324.

Fanon, F. (1952). Black skins, White masks. New York, NY: Grove Press.

Fournier, S., \& Crey, E. (2011). "Killing the Indian in the child": Four centuries of church-run schools. In M. J. Cannon \& L. Sunseri (Eds.), Racism, colonialism and Indigeneity in Canada (pp. 173-176). Don Mills, ON: Oxford University Press.

Francis, D. (2000). The imaginary Indian: The image of the Indian in Canadian culture. Vancouver, BC: Arsenal Pulp Press.

Galabuzi, G. (2011). Hegemonies, continuities, and discontinuities of multiculturalism and the Anglo-Franco conformity order. In M. Chazan, L. Helps, A. Stanley, \& 
S. Thakkar (Eds.), Home and Native land: Unsettling Multiculturalism in Canada (pp. 58-82). Toronto, ON: Between the Lines.

Gillborn, D. (2005). Education policy as an act of White supremacy: Whiteness, critical race theory and education reform. Journal of Education Policy, 20(4), 485-505.

Goulet, L. (2001). Two teachers of Aboriginal students: Effective practice in sociohistorical realities. Canadian Journal of Native Education, 25, 68-82.

Goulet, L. (2005). Creating culturally meaningful learning environments: Teacher actions to engage Aboriginal students in learning (Doctoral dissertation). Regina, Saskatchewan: University of Regina.

Hall, S. (1997). The spectacle of the "other." In S. Hall (Ed.), Representation: Cultural representations and signifying practices (pp. 223-291). London, UK: SAGE Publications.

Henderson, J. S. (2009). Ayukpachi: Empowering Aboriginal thought. In M. Battiste (Ed.), Reclaiming Indigenous voice and vision (pp. 248-278). Vancouver, BC: UBC Press.

Howard, H., \& Proulx, C. (2011). Introduction. In H. Howard \& C. Proulx (Eds.), Aboriginal people in Canadian cities: Transformations and continuities (pp. 122). Waterloo, ON: Wilfred Laurier Press.

Iseke-Barnes, J. (2008). Pedagogies for decolonizing. Alberta Journal of Educational Research, 48(2), 98-121.

Kanu, Y. (2002). In their own voices: First Nations students identify some cultural mediators of their learning in the formal school system. The Alberta Journal of Educational Research, 48(2), 98-121.

Kanu, Y. (2005). Teachers' perceptions of the integration of Aboriginal culture into the high school curriculum. The Alberta Journal of Educational Research, 51(1), 50-68.

Kincheloe, J., \& Steinberg, S. (2008). Indigenous knowledges in education: Complexities, dangers, and profound beliefs. In N. Denzin, Y. Lincoln, \& L. Tuhiwai Smith (Eds.), Handbook of critical and Indigenous methodologies (pp. 135-156). Thousand Oaks, CA: SAGE Publications.

Kirkness, V. J. (1998). Our peoples' education: Cut the shackles; cut the crap; cut the mustard. Canadian Journal of Native Education; 22(1), 10-15.

Laeuni, P. (2009). Hawaiian statehood revisited. In M. Battiste (Ed.), Reclaiming Indigenous voice and vision (pp. 50-56). Vancouver, BC: University of British Columbia Press.

Lawrence, B. (2004). "Real" Indians and Others: Mixed-blood urban native peoples and Indigenous nationhood. Vancouver, BC: University of British Columbia Press. 
Lawrence, B., \& Dua, E. (2011). Decolonizing antiracism. In M. J. Cannon \& L. Sunseri (Eds.), Racism, colonialism and Indigeneity in Canada (pp. 19-28). Don Mills, ON: Oxford University Press.

Leavitt, R. (1995). Language and culture content in Aboriginal education. In M. Battise \& J. Barman (Eds.), First Nations education in Canada: The circle unfolds (pp. 124-138). Vancouver, BC: University of British Columbia Press.

Lewontin, R. (1972). The apportionment of human diversity. Evolutionary Biology, 6, 381-398.

Little Bear, L. (2000). Forward. In G. Cajete, Native science: Natural laws of interdependence (pp. ix-vii). Santa Fe, NM: Clear Light Publishers.

MacIver, M. (2012). Aboriginal students' perspectives on the factors influencing high school completion. Multicultural Perspectives, 14(3), 156-162.

Mackey, E. (2002). The house of difference: Cultural politics and national identity in Canada. Toronto, ON: University of Toronto Press.

Mackey, E. (2012). Tricky myths: Settler pasts and landscapes of innocence. In N. Neatby \& P. Hodgins (Eds.), Settling and unsettling memories: Essays in Canadian public history (pp. 310-339). Toronto, ON: University of Toronto Press.

Melnechenko, L., \& Horseman, H. (1998, December). Factors that contribute to Aboriginal students' success in school in Grades six to nine. [Amicus Monograph No. 23673275]. Regina, Saskatchewan: Saskatchewan Education.

Memmi, A. (2000). Racism. Minneapolis, MN: University of Minnesota Press.

Miller, J. R. (2001). Skyscrapers hide the heavens: A history of Indian-White relations in Canada $\left(3^{\text {rd }}\right.$ ed.). Toronto, ON: University of Toronto Press.

Miller, J. R. (2009). Shingwauk's vision: A history of Native residential schools. Toronto, ON: University of Toronto Press.

minority (2013, March). In OED Online. Retrieved from http://www.oed.com.login.ezproxy.library.ualberta.ca/view/Entry/118943?redire ctedFrom $=$ minority.

National Indian Brotherhood/Assembly of First Nations (1972). Indian control of Indian education. Retrieved from http://64.26.129.156/calltoaction/Documents/ICOIE.pdf

Neegan, E. (2005): Excuse me: Who are the first peoples of Canada? A historical analysis of Aboriginal education in Canada then and now. International Journal of Inclusive Education, 9(1), 3-15. Retrieved from http://www.cla.sd57.bc.ca/fileadmin/sites/cla.sd57.bc.ca/SPSS/ab ed/erica neega $\underline{\mathrm{n} \text { EXCUSE ME.pdf }}$ 
O’Brien, S., \& Szeman, I. (2004). Popular culture: A user's guide. Scarborough, ON: Nelson.

Ontario Ministry of Education. (2007a). Aboriginal education in Ontario. Toronto, ON: Queen's Printers, Inc. Retrieved from http://www.edu.gov.on.ca/eng/aboriginal/new resources.pdf

Ontario Ministry of Education. (2007b). Toronto, ON: Queen's Printers, Inc. First Nation, Métis and Inuit educational policy framework. Retrieved from http://www.edu.gov.on.ca/eng/aboriginal/fnmiframework.pdf.

Ontario Ministry of Education. (2009). Realizing the promise of diversity: Ontario's equity and inclusive education strategy. Toronto, ON: Queen's Printers, Inc. Retrieved from http://www.edu.gov.on.ca/eng/policyfunding/equity.pdf

Ontario Ministry of Education. (n. d.). Thinking literacy: Cross-curricular approaches, grades 7-12. Retrieved from http://www.edu.gov.on.ca/eng/studentsuccess/thinkliteracy/files/ThinkLitHistory Civics.pdf

Orlowski, P. (2008). "That would certainly be spoiling them": Liberal discourses of social studies teachers and concerns about Aboriginal students. Canadian Journal of Native Education, 31(2), 110-129.

Razack, S. (2007). When place becomes race. In T. Das Gupta, C. E. James, R. C. A. Maaka, G. Galabuzi, \& C. Andersen (Eds.), Race and racialization: Essential readings (pp. 74-82). Toronto, ON: Canadian Scholars Press, Inc.

Redwing Saunders, S. E., \& Hill, S. M. (2007). Native education and in-classroom coalitions-building: Factors and models in delivering an equitous authentic education. Canadian Journal of Education, 30, 1015-1045. Retrieved from http://www.jstor.org/stable/20466677

Regan, P. (2010). Unsettling the settler within: Indian residential schools, truth telling and reconciliation in Canada. Vancouver, BC: University of British Columbia Press.

Restoule, J. (2011). Everything is alive and everyone is related: Indigenous inclusive education. In C. Rolheiser, M. Evans, \& M. Gambhir (Eds.), Inquiry into practice: Reaching every student through inclusive curriculum (pp. 17-19).

Rolheiser, C., Evans, M., \& Gambhir, M. (2011). Towards inclusive curriculum: perspectives, practices, and possibilities. In C. Rolheiser, M. Evans, \& M. Gambhir (Eds.), Inquiry into practice: Reaching every student through inclusive curriculum (pp. 3-7). Retrieved from http://www.oise.utoronto.ca/oise/UserFiles/File/ITE_PUB_2011_COMPLETE_L $\underline{\mathrm{R} 1 . p d f}$

Said, E. (1978). Orientalism. New York, NY: Random House. 
Sapon-Shevin, D. (1999). Your heart is a muscle the size of your fist. Keep loving, keep fighting. Woodcut Art. Retrieved from http://media-cacheec0.pinimg.com/originals/f3/41/4c/f3414c71a1244a3c873b2b37e289944f.jpg

Schissel, B., \& Wotherspoon, T. (2003). The legacy of school for Aboriginal people: Education, oppression, and emancipation. Don Mills, ON: Oxford University Press.

Schmitt, R. (1996). Racism and objectification: Reflections on themes from Fanon. In L. Gordon, T. Sharpley-Whiting, \& R. White (Eds.), Fanon: A critical reader (pp. 35-50). Oxford, UK: Blackwell.

Sensoy, Ö., \& DiAngelo, R. (2012). Is everyone really equal? An introduction to key concepts in social justice education. New York, NY: Teacher's College Press.

settler. (2013, March). In OED Online. Retrieved from http://www.oed.com.login.ezproxy.library.ualberta.ca/view/Entry/176873?redire ctedFrom $=$ settler

Silver, J., Mallett, K., Greene, J., \& Simard, F. (2002). Aboriginal education in Winnipeg inner city high schools. Ottawa, ON: Canadian Centre for Policy Alternatives. (ERIC Document Reproduction Service No. ED 476938).

Simpson, J. S., James, C. E., \& Mack, J. (2011). Multiculturalism, colonialism, and racialization: Conceptual starting points. Review of Education, Pedagogy, and Cultural Studies, 33(4), 285-305. doi: 10.1080/10714413.2011.597637

Simpson, L. (2008). Oshkimaadiziig, the new people. In L. Simpson (Ed.), Lighting the eighth fire: The liberation, resurgence and protection of Indigenous nations (pp. 13-22). Winnipeg, MB: Arbeiter Ring Publishing.

Smith, L. T. (1999/2012). Decolonizing methodologies: Research and Indigenous peoples ( $2^{\text {nd }}$ ed.). London, UK: Zed Books.

St. Denis, V. (2009). Rethinking culture theory in Aboriginal education. In C. LevineRasky (Ed.), Canadian perspectives on the sociology of education (pp. 163-182). Toronto, ON: Oxford University Press.

St. Denis, V. (2011). Silencing Aboriginal curricular content and perspectives through multiculturalism: "There are other children here." Review of Education, Pedagogy, and Cultural Studies, 33(4), 306-317.

St. Denis, V., \& Schick, C. (2003). What makes anti-racist pedagogy in teacher education difficult? Three popular ideological assumptions. The Alberta Journal of Educational Research, 49(1), 55-69.

Sterzuk, A. (2010). Indigenous English and standard language ideology: Toward a postcolonial view of English in teacher education. Canadian Journal of Native Education, 32, 100-113. 
Stewart-Harawira, M. (2005). Cultural studies, Indigenous Knowledge and pedagogies of hope. Policy Futures in Education, 3(2), 153-163.

Taylor, J. (1995). Non-Native teachers teaching in Native communities. In M. Battiste \& J. Barman (Eds.) First Nations education in Canada: The circle unfolds (pp. 224-244). Vancouver, BC: UBC Press.

Thobani, S. (2007). Exalted subjects: Studies in the making of race and nation in Canada. Toronto, ON: University of Toronto Press.

Thompson, A. (2003). Tiffany, friend of people of colour: White investments in antiracism. International Journal of Qualitative Studies in Education, 16(1), 729.

Vickers, J., \& Issac, A. (2012). The politics of race: Canada, the United States and Australia $\left(2^{\text {nd }}\right.$ ed.). Toronto, ON: University of Toronto Press.

Walcott, R. (2011). Disgraceful: Intellectual dishonesty, White anxieties, and multicultural critique thirty-six years later. In M. Chazan, L. Helps, A. Stanley, \& S. Thakkar (Eds.), Home and Native land: Unsettling Multiculturalism in Canada (pp. 15-30). Toronto, ON: Between the Lines.

Wilson, S., \& Wilson, P., (2002). Editorial: First Nations education in mainstream systems.Canadian Journal of Native Education, 26(2), 67-8.

Wotherspoon, T. (2009). The sociology of education in Canada ( $3^{\text {rd }}$ ed.). Don Mills, ON: Oxford University Press.

Wotherspoon, T., and Satzewich, V. (2000). First Nations: Race, class and gender relations. Saskatoon, SK: Canadian Plains Research Centre.

Young, R. J. C. (2003). Introduction: Montage. In R. J. C. Young (Ed.), Postcolonialism: A very short introduction (pp. 1-8). Don Mills, ON: Oxford University Press.

\section{Endnotes}

1 This is based in part on the Oxford English Dictionary's (2013) explanation of decolonization.

${ }^{2}$ In the Canadian context, I use the term "Indigenous children" to refer to children of First Nation, Métis and/or Inuit decent.

${ }^{3}$ Laeuni (2009) identifies the first step as rediscovery and recovery, and the second as mourning.

${ }^{4}$ I use "minorities" here with the understanding that non-White peoples are considered "a small or select group of people" (minority, 2013) in terms of their social and political power even though many so-called racial groups have populations substantially larger than that of Whites. 
${ }^{5}$ As Dalia Sapon-Shevin (1999) so eloquently stated, "The heart is a muscle the size of your fist. Keep loving, keep fighting." Or, in other words, don't give up.

${ }^{6}$ The other half (or more) of their education was deemed practical not only according to gender-boys would learn farming skills and contribute the labour needed to run residential schools such as maintaining the grounds and farming while girls learned the domestic skills also required to keep students fed and with clean laundry (Dickason, 2006, 2009; Miller, 2009) - but also because it was assumed that Indigenous children were not as intelligent as settler children.

7 This manifested in the Indian Control of Indian Education (National Indian Brotherhood, 1972) which advocated for Indigenous students to receive both academic and cultural training in their school environment.

8 Alfred (2005) explains Onkwehonwe as the "original people," that is, Indigenous people. 